школа. - 1966. - №5. - С. 44-50. 5. Программы педагогических институтов. Основы научной организации педагогического труда : спецкурс. - М. : УМС при МП, 1982. - 23 с.

\title{
ФОРМУВАННЯ В ДОШКІЛЬНИКІВ ЦІННІСНОГО СТАВЛЕННЯ ДО СВОЇХ БАЗОВИХ ОБОВ'ЯЗКІВ ЯК ПСИХОЛОГО-ПЕДАГОГІЧНА ПРОБЛЕМА
}

Тукач I. І. Формування в дошкільників ціннісного ставлення до своїх базових обов'язків як психолого-педагогічна проблема.

У статті проаналізовано стан дослідження проблеми формування ціннісного ставлення дітей дошкільного віку до своїх базових обов'язків шляхом окреслення базових понять «мораль», «обов'язок» «ціннісне ставлення» у психолого-педагогічній літературі.

Ключові слова: дошкільник, обов'язок, мораль, ціннісне ставлення.

Тукач И. И. Формирование у дошкольников ценностного отношения к своим базовым обязанностям как психолого-педагогическая проблема.

В статье проанализировано состояние исследования проблемы формирования ценностного отношения детей дошкольного возраста к своим базовым обязанностям путем определения базовых понятий «мораль», «обязанность», «ценностное отношение» в психолого-педагогической литературе.

Ключевые слова: дошкольник, обязанность, мораль, ценностное отношение.

Tukach I. I. Forming preschoolers valuable attitude to their basic duties as psycho-pedagogical problem.

The article analyzes the research on the formation of value treatment of preschool children with their basic responsibilities by outlining the basic concepts of «morality», «duty», «value treatment» in psychological and pedagogical literature.

Key words: preschool, duty, morality, value treatment.

Кожна людина, особливо в дитинстві, потребує любові та піклування, доброзичливого ставлення до себе, відчуття своєї необхідності, значущості, прийняття і розуміння нею необхідності існування прав та обов'язків у процесі життєдіяльності. Ці чинники впливають на повноцінний особистісний розвиток дитини, моральних, правових та етичних норм пї поведінки.

Відомо, що обов'язки виникають не з народження людини, а поступово, в процесі становлення в онтогенезі та включення індивіда в суспільні відносини, пов'язані 3 виконанням рольових зобов'язань, зумовлених віком, місцем особистості в системі цих відносин.

У філософській, педагогічній, психологічній літературі зміст поняття «обов’язок» розкривається у різноманітних смислах.

У тлумачному словнику української мови зазначено, що «обов'язок - це те, що підлягає безумовному виконанню внаслідок суспільних вимог або внутрішніх стимулів; певний обсяг роботи, справ, що визначається званням, посадою тощо» [12, с. 210].

У сучасному суспільстві обов'язки переважають у таких соціальних інститутах, як моральність і право. За висловом В. Перевалова, обов'язки поділяються на природні, носіями яких виступають людина і суспільство, та юридичні, носіями яких є громадяни, держава, iї органи. Природні обов'язки відповідають основним природним правам людини $[14$, с. $502-503]$.

К. Ушинський розглядав обов'язок як умову успішної навчальної діяльності. Він рекомендував учителям із перших уроків привчати дитину полюбити свої обов'язки i 
«знаходити приємність у їх виконанні» [267, с. 273]. Процес виховання обов’язку, на думку педагога, розпочинається з початкової ланки, коли досягаються суттєві зрушення в загальному розвитку учнів, формується бажання й уміння вчитися. К. Ушинський пов'язував почуття обов'язку з підготовкою дитини до життя, де від іï вміння сумлінно і свідомо виконувати свої зобов'язання залежать наслідки майбутніх дій, досягнення чи недосягнення тієї чи тієї людської мети в житті. «Привчіть же дитину робити не тільки те, що іiі цікавить, але й те, що не цікавить, - робити заради приємності виконати свій обов'язок. Ви готуєте дитину до життя, а в житті не всі обов'язки цікаві...» [18, с. 274].

С. Русова наголошувала на тому, що вихователь має формувати в дітей потребу в дотриманні обов'язку щодо виконання ними малих справ. Одним із засобів, на думку науковця, є гра. С. Русова [16] підкреслює, що в грі розвиваються моральні якості та добрі почуття (справедливість, доброчесність, сердечність, відповідальність, почуття дружби, взаємодопомоги тощо). Тому педагог непомітно для дитини має спрямовувати гру в таке виховне русло, що приводило б до позитивних результатів.

Г.Плеханов зазначає, що основною характеристикою обов'язку як елементу моральності $\epsilon$ належна поведінка. Він стверджує: «морально-етичне виховання особистості в тому і полягає, щоб прищепити кожному знання своїх обов'язків по відношенню до інших» [15, с. 678]. Науковець наголошує, що здійснення належної поведінки, заснованої на вимогах моралі забезпечується як внутрішніми настановами самої особистості (почуття внутрішнього обов'язку), так і за допомогою зовнішньої дії (суспільством, окремими індивідами тощо). Виникнення у суб'єкта почуття внутрішнього обов'язку формується протягом довгого часу позитивним ставленням до моральної вимоги. Реалізація внутрішнього обов'язку припускає втілення в життя ціннісних абсолютів, які не несуть у собі негативного змісту. Цілком закономірно, що мотивація виконання морального обов'язку в більшості випадків є позитивною [15].

У контексті сказаного набуває особливого значення думка А. Гусейнова, І. Кона, що «обов'язок - суспільна необхідність, висловлена в моральних вимогах у такій формі, у якій вона виступає перед особистістю. Обов'язок - це ставлення особистості до суспільства. Особистість виступає тут як активний носій певних моральних обов'язків перед суспільством (суб'єкт), який усвідомлює їх і реалізує у своїй діяльності» [17, с. 75].

Національна доктрина розвитку освіти України у XXI столітті, Закон України «Про дошкільну освіту», Базовий компонент дошкільної освіти в Україні, Базова програма розвитку дитини дошкільного віку «Я у Світі» спрямовують фахівців у галузі дошкільної освіти на посилення уваги до формування в дітей дошкільного віку довіри до своїх можливостей, незалежності й автономності від допомоги і керівництва дорослих, упевненості в собі як базових обов'язків дошкільників.

У Коментарі до Базового компонента дошкільної освіти в Україні поняття «обов'язок» розглядається як моральне почуття, що грунтується на усвідомленні та прийнятті людиною соціальних норм, які перетворюються на мотив іiі діяльності. Отже, за допомогою обов'язку встановлюється баланс між можливою і належною поведінкою [10, c. 191-192].

У Базовій програмі розвитку дитини дошкільного віку «Я у Світі» зазначається, що одним із основних завдань дошкільної освіти на сучасному етапі $є$ забезпечення дітей дошкільного віку знаннями про свої обов'язки, які дозволяють дитина означити словами цю категорію; формування в дошкільників умінь назвати і виконати свої основні обов'язки (самостійно виконувати те, що по силі; не робити шкоди іншому; дотримуватися режиму дня) тощо [1, с. 273].

Отже, обов'язок у моральному вимірі може бути охарактеризований як належна поведінка, заснована на вимогах моралі і забезпечена переважно внутрішніми настановами.

Метою статті є висвітлення проблеми формування у старших дошкільників ціннісного ставлення до своїх базових обов'язків шляхом окреслення базових понять «мораль», 
«обов’язок» у психолого-педагогічній літературі.

Дослідження окремих аспектів проблеми обов'язку, обов'язковості знайшли висвітлення у працях Н. Басюк, Л. Гладких, С. Слканова, О. Жаворонко та інших.

Як підкреслює С. Слканов, самих знань своїх обов’язків та позитивного ставлення до них (намагання їх виконати) недостатньо. Обов'язок, на його думку, передбачає здатність особистості контролювати свої дії. Автор визначає такі основні компоненти: знання особистістю своїх обов'язків, важливих як для неї, так і для суспільства; прийняття цих вимог, позитивне ставлення до них, прагнення їх виконати; здатність особистості контролювати свою поведінку, вносити певні корективи в діяльність [6].

Вивчаючи проблему виховання відповідальності у школярів, О. Жаворонко включає до структури відповідальності усвідомлення індивідом своїх обов'язків і наявність у нього прагнення виконати доручене або взяте на себе зобов'язання максимально добре i старанно, при цьому виявити творчі здібності, ініціативу, винахідливість. Авторкою виокремлено у структурі відповідальності два компоненти - усвідомлення школярем необхідності виконати свої обов'язки і готовність це робити. Вона показала, що центральною ланкою у формуванні цієї якості $є$ усвідомлення учнем поставлених перед ним вимог [7].

Вивченням проблеми формування почуття відповідальності у молодших школярів опікувалися Н. Басюк. Згідно з позицією дослідниці, відповідальність як поняття, яке характеризує моральну діяльність людини, тісно пов'язана з категорією обов'язку [2].

Науковець переконує, що обов'язок - категорія складна. 3 одного боку - об'єктивна, є впровадженням громадських, суспільних вимог до людини: необхідності працювати, дотримуватися існуючих правил співжиття, виявляти нетерпимість до аморальних вчинків тощо. Зміст цих вимог не залежить від людини, вони народжені життєвою необхідністю, у них висловлені важливі умови людського існування. 3 іншого боку, обов'язок має суб'єктивний характер; це не що інше, як усвідомлення людиною вимог суспільства, колективу і внутрішня готовність, здатність свідомо, добровільно дотримувати їх у своєму житті. Авторка стверджує, що відповідальність ширше обов'язку, вона передбачає не лише необхідність, але й потребу діяти певним чином [2].

Л. Гладких наголошує, що обов'язки виступають як засіб формування «самодисципліни особистості». В обов'язках встановлення меж поведінки має принципове значення, адже справедливість, покладена в основу обов'язку, урівноважує права. Через це суб'єкту обов'язку надається тільки один варіант поведінки - належна, що дозволяє йому залишатися в межах правового поля - виконати покладений на нього обов'язок. I виконати саме так, як цього вимагає справедливість, що міститься в обов'язку [5].

Як бачимо, обов'язки дозволяють особистості лояльно користуватися своїми правами, формують і розвивають у неї правові знання, цінності, навички й уміння активної діяльності.

Спираючись на дослідницький доробок I. Беха, Г. Бєлєнької, О. Запорожця, В. Зеньковського, Р. Ібрагімової, О. Кононко, В. Мухіної, Н. Непомнящої, Т. Поніманської, констатуємо, що саме старший дошкільний вік є найсприятливішим віковим періодом, у який закладається основа усвідомленого, ціннісного ставлення дошкільників до своїх прав та обов'язків. Діти цього віку виявляють розвинене цілеспрямоване сприймання, довільну пам'ять, вміння аналізувати й узагальнювати інформацію. У них відбувається інтенсивний розвиток мислення.

Як засвідчує В. Мухіна, майже всі шестирічні діти не лише усвідомлюють себе суб'єктом, а й відчувають потребу реалізувати себе в якості суб'єкта: увійти у широке коло суспільних відносин, мотивувати свою діяльність почуттям обов'язку [13, с. 243]. Якщо на ранніх етапах дошкільного дитинства діти виконують певну роботу лише задля власного задоволення або схвалення дорослих, то старші дошкільники починають виконувати обов'язки не заради схвалення або досягнення лідерства, а прагнучи задовольнити потреби оточуючих людей $[13$, с. 47]. Це засвідчує перетворення засвоєних дитиною соціальних норм і вимог на 
внутрішні мотиви іï поведінки.

Г.Бєлєнька наголошує, що старший дошкільний вік відзначається розвитком смислових орієнтацій, формуванням моральних уявлень та оцінки, формуються первинні етичні норми поведінки. Діти, у яких виражено почуття власного «Я», відстоюють свою точку зору, виявляють активність і нетерпимі до авторитарного тону, принижень, покарань [4].

На думку І. Беха, підростаюча особистість має набути досвіду відповідальної свободи вибору. Досвід вільного і відповідального вибору $є$ одним із найглибших джерел позитивних особистісних змін. Свобода буде обманом без усвідомлення своїх прав i обов'язків [3].

Усюди, де дитина може реалізовувати свої бажання, вона переживає бадьоре усвідомлення своїх сил, безпосередньо переживає своє «право» на самостійну активність, - і усюди, де вона не сміє, не може здійснити того, що хоче, де повинна пристосовуватися, у неї розвивається свідомість кордонів ії сил, свідомість слабкості, навіть безсилля. На думку В. Зеньковського, перше відчуття має позитивне значення, друге, - негативне; перше піднімає загальний настрій, створює творчі імпульси, будить нові сили, ставить нові завдання, манить дитину до все нової і нової діяльності. Успіх окриляє їі, піднімає тон іiї самопочуття, вселяє віру в себе. І навпаки, відчуття своєї слабкості має зовсім інший вплив - воно заставляє дитину відмовлятися від своїх планів і намірів, змушує підкорятися чужій волі, викликає хворобливий утиск в особі, підриває віру в себе. Дитина пристосовується до інших, відчуває себе нездібною, непридатною. Нормально, що в нашій душі, зауважує науковець, живуть обидва відчуття, взаємно врівноважуючи один одного $[8$, c. 145$]$.

Якщо в ранньому дитинстві, стверджує В. Зеньковський, відсутня «егоцентрична установка», немає культу свого «я», дитина, не усвідомлюючи цього, все ж весь час зайнята собою, глибоко переживаючи і радощі, і горе, і успіхи, і невдачі. На його думку, старший дошкільний вік - це час втрати дитиною своєї егоцентричної позиції [8, с. 145]. Відтак, із втратою егоцентричності, дитина в змозі дивитися на навколишній світ не лише з власної, але й інших точок зору. Їй відкривається смисл своїх дій і вчинків, здатність передбачати їхні наслідки для оточуючих і самої себе.

Отже, науковець поняття соціального розвитку кваліфікує, як баланс розвиненого «Я» $\mathrm{i}$ соціальної спрямованості. Тільки тоді, стверджує він, коли це буде збалансовано, можна говорити про належний соціальний розвиток особистості, тобто входження дитини в соціум і збереження задоволення своїх прав і вміння дотримуватися своїх обов'язків.

Для нашого дослідження надзвичайно актуальними $\epsilon$ теоретичні узагальнення російського психолога Р. Ібрагімової, згідно з якими при постійній підтримці перших виявів почуття обов'язку в дітей спостерігається закріплення в їхній поведінці таких позитивних рис, як чуйність, передбачливість, дбайливість про інших людей. Помітно позитивний вплив мають вияви почуття обов'язку на тих дітей, у яких через неправильне виховання починають окреслюватися негативні риси в їх поведінці, а саме: егоїзм, грубість, нечутливе ставлення до інших людей, неповага до дорослих, неувага до менших. Як зазначає науковець, із виникненням та розвитком зачатків почуття обов'язку, починаючи з дошкільного віку, закладаються основи етичної поведінки [9].

Висновки, яких дійшла Р. Ібрагімова у результаті вивчення зачатків почуття обов'язку, надали підстави стверджувати, що виховання почуття обов'язку у дітей повинно починатися рано, а саме з дошкільного віку, і складати основу формування в них навиків етичної поведінки як важливого і необхідного його компонента [9]. Оскільки почуття обов'язку не розвивається саме собою, його розвиток вимагає активного втручання дорослих. Вихователям і батькам не слід чекати, коли воно з'явиться і пустить свої перші паростки, а необхідно будити його - викликати до життя там і тоді, де і коли його немає, підтримувати його перші вияви і цим сприяти зміцненню і подальшому розвитку [9].

Цікавими в контексті нашого дослідження є погляди О. Кононко, яка зазначає, що 
регламентованість поведінки, зовнішня слухняність, обов'язковість завершення розпочатої справи - необхідні умови нормального соціального розвитку дитини. Однак це не означає, вважає науковець, що неслухняна дитина обов'язково виросте поганою, схильною до аморальних вчинків людиною, а слухняна й відповідальна - перетвориться у гармонійно розвинену творчу особистість [11].

За даними досліджень О. Кононко, дорослі частіше нагадують дітям про обов'язки, які слід виконувати, і значно рідше у спілкуванні з ними турбуються про додержання прав дитини. Маленьким дітям майже ніколи не пояснюють, що таке «право», як воно співвідноситься 3 обов'язками, які права $\epsilon$ в них і у дорослих людей. Для розвитку самосвідомості дошкільникові необхідно мати уявлення і про свої права, і про свої обов'язки [11, с. 127]. Тому, на думку науковців, слід актуалізувати важливість створення на етапі дошкільного віку належних умов для реалізації зростаючою особистістю зафіксованих Конвенцією прав на збереження своєї індивідуальності, на свободу вибору, на захищеність від посягання на її фізичне та душевне здоров'я [11].

Отже, аналіз науково-педагогічної літератури дозволяє констатувати, що старший дошкільний вік можна вважати сприятливим віковим періодом для формування у дошкільників ціннісного ставлення до своїх базових обов'язків, а саме: бути незалежними, автономним від допомоги і керівництва дорослих, самостійним у тих ситуаціях, на які вистачає власного досвіду, прихильно ставитися до дорослих.

\section{Література}

1. Базова програма розвитку дитини дошкільного віку «Я у Світі» / М-во освіти і науки України, Акад. пед. наук України; наук. ред. та упоряд. О. Л. Кононко - [3-тє вид., випр.]. - К.: Світич, 2009. 430 с. 2. Басюк Н. А. Формування почуття відповідальності у молодших школярів : автореф. дис. на здобуття наук. ступеня канд. пед. наук : спец. 13.00.07 «Теорія і методика виховання»/ Басюк Наталія Анатоліївна. - К., 2005. - 21 с. 3. Бех І. Д. Виховання особистості: [у 2-х кн.]. - Кн. 1: Особистісно-орієнтований підхід: теоретико-технологічні засади / І. Д. Бех. - К. : Либідь, 2003. - 280 с. 4. Бєлєнька Г. Взаємозв'язок фізичного та інтелектуального розвитку дошкільника в процесі пізнання ним світу природи / Г. Бєлєнька // Наукові записки Тернопільського держ. пед. універ-ту. Серія: Педагогіка. - 2004. - № 4. - С. 55-58. 5. Гладких Л. П. Педагогические условия подготовки педагогов к духовно-нравственному воспитанию детей дошкольного возраста: автореф. дис. на соискание ученой степени канд. пед. наук: 13.00 .08 - «Теория и методика профессионального образования〉 / Гладких Любовь Петровна. - Курск, 2005. - 19 с. 6. Елканов С. Б. Воспитание и самовоспитание ответственности у подростков: автореф. дис. на соискание ученой степени канд. пед. наук: 13.00.01 : «Общая педагогика, история педагогики и образования» / С. Б. Елканов. - М., 1971. - 21 с. 7. Жаворонко А. И. О воспитании ответственности у школьников / А.И. Жаворонков // Советская педагогика. - 1960. - № 3. - С. 39-45. 8. Зеньковский В. В. Психология детства / В. В. Зеньковский. - М. : ИЦ «Академия», 1996. - 225 с. 9. Ибрагимова Р. Н. Первые зачатки чувства долга у детей дошкольного возраста: автореф. дис. на соискание ученой степени канд. пед. наук: 13.00 .08 : «Теория и методика профессионального образования» / Рената Ибрагимова. Москва, 1952. - 18 с. 10. Коментар до Базового компонента дошкільної освіти в Україні: [наук.метод. посіб.] / Наук. ред. О. Л. Кононко. - К. : Ред. журн. «Дошкільне виховання», 2003. - 243 с. 11. Кононко О. Л. Соціально-емоційний розвиток особистості (в дошкільному дитинстві): [навч. посіб. для вузів] / Олена Леонтіївна Кононко. - К. : Освіта, 1998. - 255 с. 12. Короткий тлумачний словник української мови / уклад. Д. Г. Гринчишин, Л. Л. Гумецька, В. Л. Карпова та ін.; відп. ред. Л. Л. Гумецька. - К. : Рад. школа, 1978. - 296 с. 13. Мухина В. С. Возрастная психология: феноменология развития, детство, отрочество: [учеб. для студ. вузов] / Валерия Сергеевна Мухина. [5-е изд., стереотип.] - М. : ИЦ «Академия», 2000. - 456 с. 18. Перевалов В. Д. Обязанности человека и гражданина / В. Д. Перевалов // Теория государства и права. - М., 1995. - 654 с. 19. Плеханов Г. В. Избранные философские произведения: [в 5 т.] / Г.В. Плеханов. - М. 1957. - Т.З. - 689 с. 20. Русова С. Ф. Вибрані педагогічні твори: [у 2 кн.] / за ред. С. І. Коваленко. - К. : Либідь, 2001. - 270 с. 21. Словарь по этике / под ред. А. А. Гусейнова, И. С. Кона. - М. : Политиздат, 1981. 430 с. 22. Ушинський К. Д. Три елементи школи / Вибрані педагогічні твори: [у 2 т.] / К. Д. Ушинський. - К. : Рад. школа, 1983. - Т. 1. Теоретичні проблеми педагогіки / за ред. О. І. Пискунова та ін. -486 с. 